\section{EL ROL DE LAS POLÍTICAS DE VIVIENDA EN LA EFICIENCIA SISTÉMICA DE LOS PAÍSES EN DESARROLLO: ANÁLISIS APLICADO A LA EXPERIENCIA EN URUGUAY'}

Altair Jesica Magri Díaz²

\section{Resumen}

Se analiza la inserción del área pública de la vivienda en la eficiencia sistémica de los Estados, aplicando el análisis de caso al proceso uruguayo, tomando como período de estudio las reformas efectuadas en gobiernos de izquierda desde 2005 al presente. Expongo y analizo la naturaleza del sector público de la vivienda, al cual defino como de carácter sistémico porque, aunado a la cuestión social, su desempeño incide en el desarrollo general del sistema productivo y financiero de un país y en su eficiencia sistémica en relación al ambiente externo. En el estudio de caso analizo las distintas etapas que muestran el cambio hacia

\section{THE ROLE OF HOUSING POLICIES IN THE SYSTEMIC EFFICIENCY OF DEVELOPING COUNTRIES: ANALYSIS APPLIED TO THE URUGUAYAN EXPERIENCE ${ }^{1}$}

Altair Jesica Magri Díaz 
una integración sistémica de la vivienda pasando de una función social a una función financiera y productiva. Como fueron transformadas las categorías de políticas: de la tradicional política social de vivienda (de carácter universal) y política de vivienda social (focalizadas) que definieron claramente el rol estatal de productor de vivienda, se incorpora recientemente a semejanza de otros países latinoamericanos el concepto de vivienda de interés social, formando de un cuasi mercado de la vivienda que soslaya la cuestión social.

\section{PALABRAS CLAVE: VIVIENDA, POLÍTICAS PÚBLICAS, EFICIENCIA SISTÉMICA.}

Fecha de recepción: 25.01.13

Fecha de aceptación: 10.09.13

1 Este artículo refleja una etapa del proyecto de investigación de la autora sobre procesos institucionales y política pública de vivienda en el Conosur, encuadrado en el programa de Grupo de Trabajo en América Latina y el Caribe sobre Hábitat Popular e Inclusión Social, grupo de investigación auspiciado por el Consejo Latinoamericano de Ciencias Sociales (CLACSO).

2 Uruguay. Politóloga, Dra. en Ciencias Sociales, especialización en Ciencia Política por la Universidad de la República. Magíster y licenciada en Ciencia Política. Docente e investigadora en régimen de dedicación total del Instituto de Ciencia Política, Facultad de Ciencias Sociales, Universidad de la República Oriental del Uruguay. Investigadora activa de la Agencia Nacional de Investigación e Innovación.

Correo electrónico: altair.magri@cienciassociales.edu.uy. of housing, which includes the transformation of its social function into a financial and productive function. These policy categories evolved as follows: from the classical (universal) social policies on housing and (targeted) social housing policies defining the role of the State in the production of dwellings, to the recent inclusion of the low-cost housing concept that replicates the experience of other Latin American countries and creates a quasi-housing market that ignores the social issue.

\section{KEYWORDS: HOUSING, PUBLIC POLICIES, SYSTEMIC EFFICIENCY}

Received: 25.01 .13

Accepted: 10.09.13

1 This paper is part of research project of the author regarding institutional processes and public policies on housing in South America, framed within the Latin America and the Caribbean Workgroup on Popular Habitat and Social Inclusion, funded by the Latin American Council of Social Sciences (CLACSO).

2 Uruguay, Political Scientist, Ph.D. in Social Sciences with a specialty in Political Sciences, University of the Republic. MA and BA in Political Sciences. Professor and Researcher, Institute of Political Sciences, Faculty of Social Sciences, University of the Republic. Researcher, National Agency on Research and Innovation. Email: altair.magri@ cienciassociales.edu.uy 


\section{Introducción}

Este artículo analiza la inserción del área pública de la vivienda en la eficiencia sistémica de los Estados. El análisis tiene un contenido general que luego aplico al análisis del caso uruguayo. Esta área pública es generalmente estudiada en su naturaleza sectorial, concebida como una razón social del Estado para el cumplimiento del derecho de la ciudadanía a la vivienda. Cuestión que si bien es cierta, pues aplica al tratamiento de políticas con destino a reducir el déficit habitacional con medidas de regulación y distribución, inhibe en cierta manera el tratamiento más profundo de un objeto de políticas complejo y multifactorial relacionado a la economía y la política por la magnitud de factores y actores que moviliza, como lo demuestran las normativas vigentes en gran cantidad de países. Se reconoce por parte de los gobiernos y organismos internacionales que la vivienda más allá del proceso que conlleva su infraestructura y financiación está ligada a la residencia de la familia, a sus hábitos y actividades laborales y culturales, conforma identidad y pertenencia, hace barrio y construye ciudad, pero se observa que las políticas públicas recomendadas por los organismos e implementadas por los gobiernos avanzan en las últimas décadas en sentido opuesto, privilegiando otros intereses vinculados al mercado financiero y productivo.

ARTíCULO: El rol de las políticas de vivienda en la eficiencia sistémica de los países en desarrollo: análisis aplicado a la experiencia en Uruguay / Altair Jesica Magri Díaz

\section{Introduction}

This paper analyzes the inclusion of the housing sector in the systemic efficiency of States. Such a study has a general content that is then applied to the analysis of the Uruguayan case. This public area is generally studied in relation to its sectoral nature, understood as a social reason of the State in fulfilling the right to housing. However, as suggested by the regulations currently in force in other countries, the treatment of policies aimed at reducing the housing deficit through regulatory and distribution measures inhibits the treatment of complex and multifactorial policy objectives related to the economy and politics due to the magnitude of factors and actors involved. Governments and international organizations agree that housing, beyond its infrastructural and funding processes, is linked to the residence, habits and job and cultural activities of a family; it also generates identity and a sense of belonging, creates neighborhoods and gives shape to the city. However, it has been observed over the last decade that the policies suggested by different bodies and those implemented by governments move in the opposite direction, favoring other interests related to the financial and productive markets.

revista invi № 79 / November 2013 / Volume № 28: 17-59 
La planificación de acciones en vivienda tiene una conceptualización política más amplia que la dotación de casa habitación en algún punto del territorio nacional. En las fases de formación de agenda, decisión e implementación de una política de vivienda entran otros factores conformando una arena de difícil resolución, producto de la complejidad que supone la distribución de recursos y la participación del sector en el crecimiento y desarrollo económico en un mundo donde los cambios sociales no son suficiente y adecuadamente acompañados por los gobiernos.

Se propone entonces que el área pública de la vivienda tiene un carácter profundamente sistémico porque esta área está involucrada en otras dimensiones de la función pública y propende a componer determinados equilibrios económicos y sociales para la realización de sus objetivos en función de la orientación sobre competitividad sistémica del Estado. Si se la supone tan sólo como una política social, tal como son declarados los fines de las instituciones que la integran (en el caso uruguayo así lo definen históricamente la carta orgánica del Banco Hipotecario del Uruguay, BHU) y los fines del Ministerio de Vivienda Ordenamiento Territorial y Medio Ambiente, MVOTMA, no es posible explicar la historia de problemas de regulación y distribución que se sostienen independientemente de las orientaciones de los respectivos gobiernos que la han asumido. Y es este carácter sistémico el que parece complicar la comprensión de las
The planning of actions in the housing sector has a political conceptualization that goes beyond the provision of dwellings across the country. There are other type of factors that take part in the agenda, decision and implementation processes of housing policies, the result being the generation of a complex scenario defined by the difficulty involved in the distribution of resources and the participation of this sector in the economic growth and development in a world where social changes are insufficiently and inappropriately supported by governments.

It is then suggested that the housing area has a markedly systemic character due to its involvement in other public spheres and the tendency it shows to favor social and economic stability with an eye to meet specific goals according to the targeting process based on systemic competitiveness. If this area is merely regarded as a social policy, as in the case of the institutions that compose it (in the Uruguayan experience, such a conception has been historically represented by the charter of the Mortgage Bank of Uruguay -BHU and the Ministry of Housing, Land Planning and Environment-MVOTMA) then is not possible to explain the history of regulatory and distribution problems that stand apart from the orientation imposed by successive governments. This systemic character complicates the understanding of the 
funciones oficiales en la elaboración de política pública y la elección de los públicos beneficiarios, arrastrándose históricamente la noción de déficit habitacional y de demanda insatisfecha cualquiera sea la orientación del gobierno. De acuerdo a informes recientes ${ }^{3}$ en Uruguay este déficit no existe, sino que, al contrario, se produce un superávit importante, encontrándose tal falencia en el encare de la orientación y elaboración de políticas. Cabe preguntarse entonces por qué los países y en nuestro caso el Uruguay continúan arrastrando inercias políticas estériles y frustraciones sociales de un imaginario que caló muy hondo en las sociedades desde las primeras décadas del siglo XX. Se produce entonces una paradoja: los gobiernos construyen un discurso con contenido social y actúan apoyados en la dimensión financiera y productiva del país, volviendo residual el contenido social.

En este artículo expongo y analizo, en primer lugar, la verdadera naturaleza del sector público de la vivienda, al cual defino como de carácter sistémico porque aunado a la cuestión social su desempeño incide en el desarrollo general del sistema productivo y financiero de un país y en su eficiencia sistémica en relación al ambiente externo. En segundo lugar, ya sobre el estudio de caso uruguayo, analizo las distintas etapas de cursos de acción que muestran el cambio paulatino hacia una integración sistémica de la vivienda, pasando de

3 Casacuberta, 2006. official functions involved in the elaboration of public policies and the selection of recipients, thus perpetuating the notion of housing deficit and unmet demand whatever the direction of the government might be. According to recent reports ${ }^{3}$, this type of deficit does not exist in Uruguay; on the contrary, there is an important surplus of it. Such a shortcoming can be identified in the matchup between the targeting and elaboration processes. It is worth questioning why the rest of the countries, and in this case Uruguay, still show sterile political inertia and social frustrations of an imaginary that had a large impact on societies during the first decades of the XX century. Then, a paradox emerges: governments develop a socially oriented discourse and operate on the basis of the financial and productive dimensions of the country, turning the social content into a residual element.

This paper presents and analyzes the real nature of the housing sector, which is defined as systemic due to its impact (in conjunction with the social issue) on the general development of the productive and financial system of a country and its systemic efficiency in relation to the external situation. There is also an analysis of the Uruguayan case and the different stages involved in the progressive

3 Casacuberta, 2006 
una función social a una función financiera y productiva. Como fue transformando las categorías de política de vivienda: de la tradicional política social de vivienda (de carácter universal) y política de vivienda social (focalizadas) que definieron claramente el rol estatal de productor de vivienda, se incorpora recientemente a semejanza de otros países latinoamericanos el concepto de vivienda de interés social, formando de un cuasi mercado de la vivienda, en función precisamente de su característica sistémica. Estas dimensiones conceptuales delimitan el rol del Estado en cuanto a tipos de intervención, públicos beneficiarios y actores intervinientes en la provisión de servicios, conformando redes que amplían el radio operativo del sector, amplificando su scope hacia otras dimensiones un tanto ajenas a la función básica de contemplar el derecho ciudadano a la vivienda.

\section{La naturaleza sistémica de las políticas públicas}

La visión sistémica considera la acción de un conjunto de sub-sistemas con capacidad de reproducir las actividades específicas y del conjunto del sistema, y estos subsistemas se relacionan entre sí para el intercambio de recursos con mayor o menor grado de dependencia según los roles, las capacidades y las relaciones intrínsecas de poder. La calidad sistémica aplicada al sector público fue definida change towards a systemic integration of housing, which includes the transformation of its social function into a financial and productive function. These housing policy categories evolved as follows: from the traditional (universal) social policies on housing and (targeted) social housing policies defining the role of the State in the production of dwellings, to the recent inclusion of the low-cost housing concept that replicates the experience of other Latin American countries and creates a quasi-housing market that ignores the social issue. Such conceptual dimensions define the role of the State in terms of intervention, recipients and actors involved in the provision of services, the result being the creation of networks that expand the operational ratio towards other dimensions alien to the basic function of monitoring the right of citizens to housing.

\section{The Systemic Nature of Public Policies}

The systemic approach can be understood as the action of a series of subsystems with the capacity to reproduce the specific and general activities of the system; these subsystems are related to each other in order to exchange resources with a greater or lesser degree of dependence based on the roles, capacities, and intrinsic power 
por Easton ${ }^{4}$ como la capacidad de respuesta que le asegura mantenerse en un sistema general de intercambios protegiendo sus procesos vitales. El recurso esencial es la capacidad de respuesta que asegura su pervivencia como subsistema público - la gobernabilidad del mismo, definida como la capacidad de desarrollar sus cometidos con eficiencia y eficacia destinada al bien público- y la gobernanza -definida como la estructura de relacionamiento con la sociedad y el mercado u otros ámbitos externos al Estado nación- ${ }^{5}$. Los instrumentos de relacionamiento son las políticas públicas, acciones con sentido que responden a demandas y/o preferencias del gobierno, que se modifican en función de tales factores ${ }^{6}$.

El transcurso del siglo XX ha mostrado las etapas de crisis y transformación del Estado moderno en respuesta a los cambios sociales y al ambiente externo. El proceso de adaptación a la industrialización capitalista que dio forma al Estado liberal, la construcción y declive del Estado keynesiano de bienestar entre guerras, con el afianzamiento de los derechos políticos y sociales; la reforma liberal de los 70 y 80 como respuesta del mercado a la expansión pública y hasta nuestros días el proceso de adecuación de los Estados nacionales a la era de

4 Easton, 1973

5 Flisfisch A., 1989; Franco R., 1993; Cerrillo i Martínez, A., 2004; Echevarría Koldo, 2005.

6 Meny y Thoenig, 1992; Aguilar Villanueva, 2006; Lahera, 2002. relationships. The application of the systemic approach to the public sector was defined by Easton $^{4}$ as the response capacity that enables this area to remain in a general system of exchanges where vital processes are protected. The essential resource is the response capacity that ensures the survival of this area as a public subsystem (known as governability, which is defined as the capacity to efficiently and effectively serve the public good and governance, defined as the relationship with the market and society or other spheres external to the nation State). ${ }^{5}$ Public policies can be defined as relationship instruments; these actions respond to the demands or preferences of the government and can be modified according to such factors. ${ }^{6}$

The twentieth century has shown the crisis and transformation stages of the modern State in response to social changes and external factors. From the adaptation process to the capitalist industrialization that gave shape to the liberal State and the construction and decline of the interwar Welfare Keynesian State and the strengthening of social and political rights; including the liberal reforms that took place in the 1970s and 1980s as the market response to public

\footnotetext{
4 Easton, 1965.

5 Flisfisch A., 1989; Franco R., 1999; Cerrillo i Martínez, A. comp., 2005; Echeverría Koldo, 2005.

6 Meny \& Thoenig, 1992; Aguilar Villanueva, 1993; Lahera, 2002.
} 
la globalización y el posfordismo ${ }^{7}$. Las transformaciones sociales en sentido amplio han incidido de manera rotunda en estos procesos. Con distintas correlaciones de fuerzas cada etapa se distinguió por una especial manera de relacionamiento del área con la sociedad y la economía y por una estructura interna particular al interior del Estado para la provisión de políticas públicas. Pero en definitiva, los Estados y sus políticas públicas "actúan en función de la eficiencia sistémica nacional del Estado, la capacidad de este de alcanzar sus objetivos de manera satisfactoria para las mayorías ciudadanas"8. Por esto, cada curso de acción con sentido de un área pública sectorial o territorial es parte del escenario sistémico donde se desenvuelve la política nacional: sistema político, corporaciones, empresas, gremios, grupos sociales, grupos transnacionales. Su elaboración debe tener en cuenta factores y actores que se desenvuelven en un sistema de incentivos e intereses para la maximización de sus expectativas. Y esto es uno de los grandes dilemas de las políticas públicas, la solución de problemas sectoriales que exceden su ámbito y, por otro lado, el logro de síntesis satisfactorias en ámbitos de negociación y colaboración amortiguando el conflicto que se desarrolla entre diferentes intereses del cuerpo social como del propio Estado, porque respuestas sectoriales entendidas como satisfactorias en función del cometido institucional y de la

7 Jessop, 2008.

8 Narbondo, 2012, p. 2. expansion to the current adaptation of national States to the globalization and post-Fordist ${ }^{7}$ era. Broadly speaking, social transformations played a key role in these processes. With different degrees of intensity, each of these stages was characterized by their relationship with the market and society and a particular internal structure for the provision of public policies. However, States and their public policies operate according to the national systemic efficiency of the State, the capacity of the former to satisfactorily achieve citizenship-oriented goals. ${ }^{8}$ This is why each course of action derived from a sectoral or territorial area is part of the systemic scenario where national political activity takes place: political system, corporations, companies, guilds, social groups and transnational groups. The development of these initiatives should consider the different factors and actors involved in a system of incentives and interests intended to maximize expectations. In this sense, the solution of sectoral problems lying outside their scope of action and the achievement of satisfactory syntheses in the negotiation and collaboration fields, with the latter reducing the conflict of interests within the social body and the State itself, represent a major dilemma for public policies. Such a problem arises

Jessop, 2008

Narbondo, 2012, p.2. 
demanda con la cual se relaciona pueden ser vistas como insatisfactorias por otros actores del ámbito estatal o privado, cuestionando la capacidad misma del área que la produce.

Estas disyuntivas son las que le dan a las políticas públicas en especial las de contenido social, una complejidad de difícil resolución, porque tienden a ser producidas en forma autónoma, alentadas por élites políticas en busca de réditos, por burocracias encastradas en el poder que otorga su función $y$ en la incidencia que tienen organismos internacionales en la política doméstica, en especial en países en desarrollo. Marshall ${ }^{9}$ entendía como uno de los grandes problemas de los Estados burocráticos la sectorialidad autorreferida que desconocía la cualidad sistémica sobre la cual descansaba el aparato público: primero porque las instituciones que atendían con políticas públicas los derechos civiles, políticos y sociales de la ciudadanía no estaban relacionadas entre sí, enmarcándose en una estructura estatal vertical y jerárquica; y segundo, cada una siguió sus propias reglas sin relacionarse porque no tenían o no entendían tener campos comunes de acción.

En América Latina el área de políticas sociales gozó durante casi cinco décadas de autonomía sustantiva en materia de manejo de recursos legales para la distribución de política sociales. Es con

9 Marshall, 1998. when satisfactory sectoral initiatives measured in terms of institutional mission and demand are labeled as unsatisfactory by actors from public or private sectors, thus casting doubts on the ability of the area from which these policies emerged.

These problems turn public policies, especially those socially oriented ones, into a complex issue given their autonomous development, promotion on the part of political elites in search for profit and bureaucracies making the most of the power they have, and the effect such initiatives have on international entities, especially on developed countries. Marshall ${ }^{9}$ identified the self-referred sectoral specific interests that denied the systemic nature upon which the public sector is based as one of the main problems of bureaucratic States: first of all, because there was no connection among the institutions that targeted the civil, political and social rights of citizens, thus allowing the emergence of a vertical and hierarchical structure; and secondly, each of these bodies followed their own rules because there were no common fields of action.

In Latin America, the area of social policies enjoyed substantive autonomy in the management of legal recourses for the provision of social policies for almost five decades. However, after the liberal

9 Marshall, 1998. 
la contracción liberal acaecida entre los setenta y ochenta que este campo pasa a depender del área de la macroeconomía, cambiando su rol y perdiendo funciones en la regulación y distribución con carácter social universal, desarrollando una focalización residual. Es en estas décadas que la cualidad de universalismo que alentaban se convierte en una orientación focalizada estratificando a la sociedad por grupos con capacidad o incapacidad de ingresos, produciendo la remercantilización de las políticas sociales ${ }^{10}$. De áreas autorreferidas funcionales a extensos grupos sociales, el ámbito social se redujo dentro del ámbito sistémico del Estado donde el cambio de rol readaptó los universos de atención en cantidad y calidad. La crisis no se reflejó sólo en lo social, sino que afectó a las instituciones que redujeron su capacidad operativa porque tuvieron que relacionarse en relación de dependencia con otras áreas estatales con mayor capacidad política para la hechura de políticas y "dejar entrar" a la arena a otros actores no públicos (mercado y grupos civiles organizados). Fue la época de la crisis de gobernabilidad institucional y el predominio de una gobernanza de mercado ${ }^{11}$.

A fines de los 90 en América Latina se van anunciando cambios en dos sentidos: por un lado, existe reconocimiento de "una nueva visión sistémica

10 Esping-Andersen, 1993.

11 Rhodes, 1997 y 2000; Pierre, 2000; Prats, 2003; Rosanvallon, 2009, entre otros autores. contraction that took place in the 1970s and 1980s, this area became part of macroeconomics, changing its role and losing its functions in the social universal regulation by adopting a residual approach. During these decades, the quality of universalism turned into a targeted orientation that stratified the society into groups sorted by earning capacity or incapacity, thus generating the recommodification of social policies..$^{10}$ From functional self-referred areas to large social groups, the social front experienced a shrinkage within the systemic sphere of the State where the change of role readapted the services provided in terms of quality and quantity. The crisis did not only affect the social environment but also the institutions. The latter, for instance, reduced their operative capacity because they had to operate under a mutually dependent mutual dependence relationship with other areas of the State with more political capacity to develop policies and "enable" the entry of new -public actors (market and organized civil groups). This was the crisis of the institutional governability and the preeminence of the market governance. ${ }^{11}$

The end of the 1990s saw the emergence of changes in Latin America. On the one side, there

10 G.E. Andersen, 1993.

11 Rhodes, 1997 and 2005; Pierre, 2000; Prats, 2000; Rosanvallon, 2009 , et al. 
- distinta a los postulados del Consenso de Washingtonque incorpora las necesidades y problemas de las personas y que incluye lo social no sólo como una externalidad del crecimiento y de la acumulación económica, sino como una preocupación central. De manera que se asiste a una revalorización del Estado. A diferencia del período anterior [...] se estima que el Estado juega un papel importante en tres campos: en la articulación de los distintos factores y actores en el proceso económico [...]; como garante de la integración de la sociedad $y$, por último, en función del nuevo protagonismo de los ciudadanos"12. Esta visión incorpora relaciones intergubernamentales, multi sectorialidad de las políticas y considera a otros actores no estatales. Fundamenta la dotación de mayor gobernabilidad a las áreas públicas, ya que les permite acometer sus funciones reformulando los límites y alcances de sus capacidades para el logro del bien público, a la vez que permite mejor gobernanza porque cambia el relacionamiento jerárquico con la sociedad y sus grupos de acuerdo a la formulación de ámbitos de concertación y negociación. Los planes y programas con orientación sistémica y aplicación instrumental basada en la gestión transversal se incrustaron en las áreas sociales de los Estados y muchas veces dependían de los ejecutivos por fuera de los ministerios sectoriales. Proliferaron los préstamos de financiación total o parcial a cargo de organismos internacionales como el Banco

12 Arriagada, 2006, p. 11. is a recognition that "a new systemic vision different to that of the Washington Consensus- that incorporates the needs and problems of people and includes the social issue not only as an externality of economic growth and accumulation, but also as a main concern. In this way, the State is revalued. In contrast to the previous period (...) the State plays an important role in three fields: the articulation of the different factors and actors involved in the economic process (...); as the guarantor of the integration of society and, lastly, a function according to the new prominence of citizens". ${ }^{12}$ Such a vision incorporates intergovernmental relationships, multisectoral specific policies and non-state actors. This approach provides more governability to public areas as it allows the undertaking of functions through the reformulation of the boundaries and scope of its capacities to serve the public good; it also improves governance as it modifies the hierarchical relationship with the society and its groups according to the formulation of agreement and negotiation spheres. All systemic plans and programs and the instrumental application based on crosscutting management were embedded in the social areas of States and, on several occasions, depended on the executives belonging to entities other than sectoral ministries. Likewise, there was a proliferation of total or partially funded loans

12 Arriagada, 2006, p. 11. 
Interamericano de Desarrollo (BID) y el Proyecto Naciones Unidas para el Desarrollo (PNUD).

Estas recetas universales relativizaron su aplicación al no modificar los indicadores de pobreza y exclusión, y se comenzó a reconocer que en un mundo globalizado y en competencia, los Estados con estos sistemas de integración interna pueden desarrollar procesos adecuados a sus trayectorias y correlaciones de fuerza históricas, manifestando diferencias en la orientación del gasto público y en especial de cómo desarrollar el campo social en relación a otros campos productivos y financieros ${ }^{13}$. En síntesis, el ámbito de las instituciones y sus políticas públicas es de una interrelación inmediata y mediata, de acuerdo a los temas-problema y los procesos históricos que transcurren. El BID reeditó en 2006 una vieja postura en la ciencia política de origen sistémico ${ }^{14}$ acerca de la incidencia de la "política de las políticas públicas" argumentando que los resultados o cursos de acción de los gobiernos hay que entenderlos como procesos de interacción del sistema político en su conjunto que receptan y procesan demandas y presiones del ámbito exterior (otros subsistemas).

Por otro lado, consecuente con la línea neoliberal surge otra postura sistémica donde la vivienda tiene un lugar especial. Se proclama que la vivienda es un valor de transacción. Esta es el ancla donde

13 Pierson, s.f. y 2006.

14 Easton, 1973; Dalh, 1989. provided by international entities such as the InterAmerican Development Bank (IADB) and the United Nations Development Program (PNUD).

These universal formulas downplayed their application by not modifying poverty and exclusion indicators; in a context defined by a globalized and competitive world, it is recognized that States can develop proper processes in line with their courses of action and historical correlations, revealing differences in the orientation of public expenses and, most especially, the development of the social sphere in relation to other productive and financial fields. ${ }^{13}$ In short, the institution and public policies spheres are immediate and long-term interrelations according to issues/ problems and historical processes. In 2006, the $I A B D$ revived an old stance of the systemic-based political sciences ${ }^{14}$ related to the effects of the "policy of public policies" by labeling the results or courses of action as interaction processes of the political system which, together, receive and process demand and pressures from external spheres (other subsystems).

Likewise, there is another systemic stance, consistent with the neoliberal line, that has to do with the special place of housing. Such a point of

13 Pierson, 1993 and 2006.

14 Easton, 1973; Dalh, 1956 
se fijó la nueva visión de la vivienda y la misión de los Estados en la materia que con bemoles convive con la otra postura. De Soto divulgó ampliamente "la otra" naturaleza sistémica de la vivienda contrariando la visión social que abonó el Estado de bienestar precedente: "[...] la propiedad provee a la economía de mercado de una infraestructura que hace responsables a las personas, fungibles a sus activos, rastreables las transacciones, todo lo cual aporta mecanismos que el sistema monetario y bancario requiere para operar y las inversiones para funcionar. Por eso la conexión entre capital y dinero para finanzas e inversiones corre a través de la propiedad"15. El acceso a la vivienda era justificado como "la canasta de oportunidades de las familias"16 desde donde se insertaban al sistema general de intercambios.

Estas dos líneas interpretativas se afianzaron y convivieron en los organismos multilaterales con incidencia en los gobiernos nacionales. Comenzó una etapa de reestructuración de las áreas públicas de la vivienda con ingredientes de ambas posturas. Los planes y programas tuvieron un componente liberal acerca del concepto de propiedad: "[...] la mayoría de los países optaron por promover los mercados inmobiliarios y la propiedad individual, privatizar los programas de vivienda sociales y desregular los mercados de financiación de la vivienda"17; así

\footnotetext{
15 Soto, 2001, p. 93.

16 Kaztman, 2000.

17 Rolnik, 2012, p. 4
}

view claims that housing has a transaction value. This is the anchor used to secure the new concept of housing and the mission of States in the topic that barely coexists with the other perspective. De Soto widely disseminated the "other" systemic nature of housing, which contradicted the social vision of the welfare State: "[...] property provides the market economy with an infrastructure that attributes responsibilities to people, turns their assets into fungible goods and makes their transactions fully traceable, thus contributing the mechanisms required by the financial and banking system to operate and those needed by the investment system to run properly. This is why property is the means that connects capital and money with finance and investment". ${ }^{15}$ The access to housing was justified as "the opportunities made available to people"16from which they entered into the general exchange system. These two interpretative lines became established and coexisted in influential multilateral systems within national governments. Public housing areas were restructured with elements from both of the abovementioned approaches. All plans and programs had a liberal component about the concept of property: "[...] a large number of countries chose to promote the housing market and individual property, privatize social housing programs and

15 Soto, 2001, p. 93.

16 Katzman, 2000.

revista invi № 79 / November 2013 / Volume № 28: 17-59 
como componentes de integración al sistema social/urbano y sus servicios: [...] importa conocer el funcionamiento de los ámbitos de interacción que pueden operar como fuente de los activos que se requieren para la integración social en cada etapa histórica, de las relaciones que se establecen pero también del comportamiento de otros actores sociales"18.

\section{La inserción del área} pública de la vivienda en la competitividad sistémica del Estado en sus diferentes etapas y orientaciones

Junto con el proceso europeo, en América Latina las áreas públicas de vivienda tienen larga data. Los orígenes se registran entre la primera y segunda década del siglo XX. Argentina, Brasil, Chile, México y Uruguay desarrollaron tempranamente el concepto de responsabilidad estatal de la llamada en la época "cuestión social de la vivienda". Adecuadas al proceso político institucional de cada país, estos sectores públicos compusieron una parte importante de los Estados del bienestar latinoamericano del siglo pasado. Muestran un proceso similar en cuanto reflejan etapas comunes: primero,

18 Kaztman, 2000b, p. 186. deregulate the markets for housing finance"17; and elements focused on the integration to the social/ urban system and its services: "[...]it is important to know the functioning of the interaction elements that may operate as the source of the assets required for social integration in each historical stage, it is equally important to recognize not only the relationships that may take place, but also the behavior of other social actors." 18

\section{The Inclusion of the Housing Area In the Systemic Competitiveness of the State Over Its Different Stages and Orientations}

Along the European process, Latin American housing policies have a long history. The origins of these initiatives date back to the first and second decades of the XX century. Argentina, Brazil, Chile, Mexico and Uruguay developed the State responsibility concept during the "social issue of housing" era. Adapted to the institutional political process of each country, these public sectors were a major element of the Latin

17 Rolnik, 2012, p. 4.

18 Katzman, 2000, p. 186. 
el Estado liberal que integra filantropía privada y asistencialismo público (higienismo); segundo, el Estado de bienestar universal que consagra derecho a la vivienda en las constituciones nacionales ${ }^{19}$; tercero, la etapa de contracción, la vivienda social residual del empuje neoliberal; y cuarto, el avance hacia un Estado que se reestructura en un péndulo entre contracción liberal y universalismo. En estas cuatro etapas se puede observar cómo la política de vivienda se acerca o se aleja de la cualidad sistémica que definimos anteriormente. En la etapa primera -liberal-, en la tercera -neoliberal- y cuarta -actual-, las políticas de vivienda en los países en desarrollo tienen una inserción potente en el sistema general porque son observadas como política regulatoria para mercados sin control (1900-1930) o como desprendimiento del Estado de funciones sociales (1980-1990); al contrario de la etapa segunda (bienestar, 1930-1970) que se autonomizó de la producción estatal, tanto por la institucionalidad generada -entes autónomos- en países latinoamericanos, como en la visión con que se elaboraron los planes y programas. En la etapa del bienestar era raro encontrar alguna relación de la vivienda con otros campos como la infraestructura, la educación o la salud (todas políticas del paquete social del Estado).

En el Estado de nuestros días y más allá de la orientación política -conservadora o progresista- los

19 Con excepción de Brasil que lo integra en la década de los 80.
American welfare State. They show a similar process as they reflect common stages: first, a liberal State that shares private philanthropy and public assistance (public health awareness); second, a universal welfare State that enshrines the right to housing in its constitution ${ }^{19}$; third, the contraction stage, the neoliberal residual social housing; and fourth, the progress towards a State that restructures itself between liberal contraction and universalism periods. These four stages show how housing policies move towards or away from the abovementioned systemic quality. In developing countries, the first (liberal), third (neoliberal) and fourth (current) stages are deeply embedded in the general system because they are seen as a regulatory policy for uncontrolled markets (1900-1930) or the detachment of social functions from State concerns (1980-1990); the second stage (welfare, 1930-1970), in contrast, achieved autonomy from the State production due to the institutional structure generated (autonomous bodies) in Latin American countries and the vision under which these plans and programs were developed. During the welfare stage, it was rare to find a relationship between housing and other fields such as infrastructure, education or health (all of them regarded as State social policies).

19 Brazil integrated this right in the 1980. 
gobiernos nacionales asumen con distintas modulaciones la responsabilidad de proveer bienes colectivos a través de funciones sociales y económicas que tienden ahora a confluir en materia de política pública como estrategia de competitividad de la nación en una era globalizada y de acumulación posfordista ${ }^{20}$.

Es entonces que la contracción funcional del Estado acaecida en la etapa neoliberal (1980-1990) no ha tenido golpes de péndulo de retornos al bienestar clásico, sino más bien reformas que contemplan a su manera una realidad social compleja, donde distintos grupos sociales tienen problemas de acceso, los mercados presionan a la liberalización y la flexibilización y fenómenos externos a los países trazan tendencias estratégicas. Lejos estamos ya del Estado inversor, productor y distribuidor de mediados del siglo XX, y no hay razones para pensar que esto pueda cambiar dadas las disposiciones que se manifiestan en la legislación y las políticas de los países latinoamericanos.

Cabe preguntarse entonces: ia qué responde que gobiernos de derecha e izquierda asuman posturas parecidas en este sentido? ¿Cuáles son los motivos (o exigencias) a los que se deben adecuar? ¿Cuál es ahora la inserción sistémica de la política de vivienda?

20 Jessop, 2008.

32 revista invi № 79 / Noviembre 2013 / Volumen № 28: 17-59
In the State of today, and beyond political orientation (whether conservative or liberal), national governments take the responsibility of providing collective goods through social and economic functions that merge, in terms of public policy, as a competitiveness strategy in a globalized and post-Fordist era ${ }^{20}$.

Therefore, the functional contraction of the State during the neoliberal stage (1980-1990) has not shown signs of returning to the classical welfare, bus has instead provided measures that reflect a complex social reality where different social groups have difficulties in terms of accessibility, markets exert pressure for achieving liberalization and flexibility and external events outline strategic trends. Gone are the days when the State led the investment, production and provision of social goods during the middle of the XX century and there are no reasons to think this situation may change given the regulations enshrined in the legislation and policies of Latin American countries.

Then, it is worth asking: Why do right-wing and left-wing governments take similar stances on this issue? What are the reasons (or demands) governments have to adapt to? How is housing policy systematically inserted?

20 Jessop, 2008. 
Para responder estas preguntas debemos primero considerar estar de acuerdo con que la vivienda es un factor de desarrollo humano y social integrando un conjunto de derechos ciudadanos como empleo, cultura, hábitat, ambiente, salud, etc. La vivienda actúa como ancla de contención y desarrollo pues fija, identifica y da pertenencia al individuo con el ambiente social, a través de la vivienda hay desarrollo si las familias producen y reproducen sociedad. Es un factor de naturaleza sistémica porque de su eficaz realización dependen otros factores que hacen al desarrollo humano. En esta concepción la vivienda como bien pierde valor si fallan otros componentes del sistema como la ocupación, la estabilidad, los salarios y la protección social. En este caso, la vivienda se transforma en una opción con valor de transacción mercantil que no fructifica como factor de desarrollo humano. Por otro lado, la propiedad por si sola no otorga estos valores, ya que la propiedad actúa sobre una única dimensión, la económica.

En cuanto a la primera pregunta, por qué las orientaciones en políticas de vivienda no difieren sustantivamente -a nuestro entender- entre orientaciones ideológicas distintas, la investigación llevó a observar que la reestructura estatal puede reconocer dos grandes tendencias que se suceden en el tiempo: a) el Estado neoliberal (1980-2000) que introduce en su cerno la lógica privada donde las instituciones públicas asumen un mix de líneas de políticas afines al mercado solapados con objetivos
In order to answer these questions it is necessary to agree that housing is a human and social development factor included in a series of citizen rights such as employment, culture, habitat, environment, etc. Housing acts as a container and development anchor that secures, identifies and gives individuals a sense of belonging to the social sphere; development through housing is possible if families produce and reproduce society. The effective implementation of this factor determines the success of other elements related to human development, thus proving the systemic nature of housing. Under this conception, the failure of factors such as employment, stability, salaries and social protection reduce the value of housing. In this case, housing turns into an option with a commercial transaction value that does not come to fruition as a human development value. In addition, property per se cannot define these values since it only operates in the economic dimension.

As for the first question regarding the reasons why housing policy orientations do not differ from a different ideological inclination, this paper observed that the State restructuration recognized two successive tendencies: $a$. the neoliberal State (1980-2000) that introduces the private logic in which public institutions adopt a mix of marketoriented lines disguised as public good, with the 
de bien público con el objetivo de crear mercado o cuasi mercado de servicios ${ }^{21}$; y b) el "nuevo" Estado (2000 en adelante) denominado por algunos autores como "neoweberianista, desarrollista o de bienestar universalista" que trata de re-desmercantilizar bienes con alternativas diferentes (aunque a veces no opuestas) al neoliberalismo orientados por ideas de izquierda ${ }^{22}$. El problema de observación es la continuidad de líneas conceptuales que se modifican o continúan entre estas dos grandes tendencias. Si en la primera vimos que el péndulo se movió hacia la remercantilización de los bienes respondiendo a la concepción ideológica del liberalismo excluyendo por "condición de clientes", en la segunda vemos que se trata de recodificar "[...] un conjunto de reformas estructurales [...] implementadas por las políticas neoliberales o el Consenso de Washington y a generar una mayor injerencia estatal, social y politica de la sociedad en la economía"23. En esta tendencia entran para el autor, componentes socioeconómicos ineludibles en un tipo de acumulación globalizado, la revalorización de la política como instrumento de comunidad democrática y tradiciones de utopismo anticapitalista que ponen a los gobiernos alineados hacia la izquierda en verdaderos cuellos de botella en resoluciones que implican no mirar al pasado del bienestar dominado por la burocracia y el clientelismo, pero

21 Maintz, 2001; Pollitt, 2007; Pierson, 2006.

22 Garretón, 2012; Narbondo, 2012; Boschi y Gaitán, 2008.

23 Garretón, 2012, p. 67. intention to create a service market ${ }^{21}$; and $b$. the "new" State (from 2000 onwards) regarded by some authors as a "neoWeberian, developmental or welfare-based" body politic that (guided by left-wing ideas ${ }^{22}$ ) tries to re-decommodificate goods with different (but not opposite) alternatives to neoliberalism. The problem to be observed is the continuity of conceptual lines that modify themselves or continue within these two large tendencies. While the first case showed an orientation towards the commodification of goods according to the ideological conception of liberalism that excluded the "consumers", the second case presents the recodification of"[...] a series of structural reforms [...] implemented by neoliberal policies or the Washington Consensus aimed at generating more State, social and political presence in the economy". ${ }^{23}$ For the author, different socioeconomic components take part in this tendency in a context defined by globalized accumulation, the revaluation of policies as an instrument of democratic community and capitalist utopian traditions that move governments towards the left. Such a switching implies avoiding looking back at the welfare dominated by bureaucracy and patronage systems, solving the character or nature of universalism,

21 Maintz, 2001; Pollit, 2007; Pierson, 2006.

22 Garretón, 2012; Narbondo, 2012; Boschi \& Gaitán, 2008.

23 Garretón, 2012, p. 67. 
también resolver el carácter o naturaleza del concepto de universalismo y aplicar instrumentos de control político que redunden en la efectividad de las políticas: el bienestar social sin perder de vista la importancia del factor vivienda en el sistema financiero y económico y su competitividad país.

La segunda pregunta, los motivos de esta adecuación del sistema neoliberal en gobiernos preocupados por restablecer la equidad y la cohesión social recuperando en nuestro caso espacio público en el área de la vivienda, encuentra algunos cauces explicativos. En primer término, los gobiernos han asumido instituciones desmanteladas en aras del mercado, vaciadas de contenido, hundidas en corrupción y sin público objetivo a atender. Para Garretón "[...] se expresa en la pérdida relativa de las funciones del Estado en cuanto a su función controladora, dirigente y proveedora, junto al debilitamiento de las grandes categorías sociales (clase obrera, clase media, estudiantes, etc.)"24. En este último aspecto, Grau argumenta que "los derechos son hoy un campo más complicado de cómo se pensaban y practicaban $a^{2} e^{\prime 25}$, por lo que profundizar en la acción política en la esfera de lo público sin los respaldos necesarios de las instituciones sociales puede seguir colaborando en este proceso lento y sostenido de decadencia del nosotros ciudadano.

24 Ibíd, p. 61.

25 Tomado de ponencia de Nuria Cunill presentada en $\mathrm{X}$ Congreso de SAAP, 2011 (sin publicar). and implementing political control instruments aimed to achieve effectiveness without losing sight of the importance of the housing factor in the political and economic systems and its countrylevel competitiveness.

The second question is related to the adaptation of the neoliberal system to governments concerned about equity and social cohesion, including the public space recovered in the process. In the first place, governments have taken control of dismantled, empty, corrupted and non-oriented institutions as the result of market activity. As Garretón suggests"[...] it is the loss of State functions in relation to its controlling, leading and supplying role alongside the weakening of major social categories (working class, mid-class, students, etc.)". ${ }^{24}$ As for this last aspect, Grau comments that "rights are more complex than they used to be"25, so further development in this public area without proper support from social institutions may contribute to this slow and constantly decaying process of the role of citizens.

With abroader sense of analysis, but still applicable to the object of study, Garreton feels that there are gaps that need to be filled in, as the welfare model

24 Ibíd,p. 61.

25 Taken from Nuria Cunill's talk presented at the X SAAP Congress, 2011 (unpublished). 
También con un sentido más amplio de análisis pero aplicable al objeto de estudio, opina Garretón que se encuentran vacíos a llenar ya que el modelo de bienestar fue deconstruido y reemplazado por un modelo excluyente y mercantilizado que luego no tuvo el reemplazo adecuado a las preferencias de los ciudadanos que optaron por partidos progresistas o de izquierda. La razón fue que la argamasa del antiguo Estado de Bienestar se formó sobre la participación, "la política era el cemento cultural de la sociedad"26, opinión también expuesta en el documento de Huntington y Watanuki en 1975 pero argumentada en contra como causante de todos los males del Estado.

En tercer término, se observa una desviación entre el discurso histórico de los partidos de izquierda y el ejercicio pragmático del poder. Vilas ${ }^{27}$ analiza que conceptos como democracia y reformas han ocupado el espacio del enfrentamiento sistémico o la revolución social. Los gobiernos progresistas actuales en el dilema de mantener los equilibrios macroeconómicos y competir en el sistema global,

26 Garretón, op cit., p. 59

27 Vilas, 2005 was deconstructed and replaced by an exclusive and commodified model that, in turn, was not properly replaced according to the preferences of citizens who voted for progressive or left-wing parties. This was due to the fact that the Welfare State was built upon participation, "politics was the cultural mortar of society"26, such an opinion was mentioned by Huntington, Crozier and Watanuki in 1975; however, this point of view was regarded as the reason for all of the ills of the State.

Thirdly, there is a departure between the historical discourse of left-wing parties and the pragmatic wielding of power. Vilas ${ }^{27}$ points out that concepts such as democracy and reforms have used the space of systemic confrontation or social revolution. Facing the dilemma of maintaining macroeconomic stability or competing in the global system, current progressive governments adopted cost contention strategies ${ }^{28}$ that involve supporting neoliberal policies focused on demand ${ }^{29}$. In the words of Rolnik ${ }^{30}$ : "[...] as the result (of this strategy),

\footnotetext{
26 Garretón, op cit., p. 59.

27 Vilas, 2005.

28 Policies reflecting variations in the behavior of public expenditure in relation to the origin, budget origin, and temporary dynamics of expenditure (Pierson, 2006).

29 Contrary to the welfare model that was aimed at recipient from different social groups, the identification of demand suggests that citizens become organized, thus generating policies and plans.

30 Rolnik, 2012, p. 4.
} 
adoptaron estrategias de contención de $\operatorname{costos}^{28}$ que supone entre otras cosas mantener líneas de política del modelo neoliberal que trabajan a la demanda ${ }^{29}$. Como bien argumenta Rolnik ${ }^{30}$ : "[...] como resultado (de esta estrategia) las ayudas a las familias para obtener créditos, el sector financiero y el mercado privado se convirtieron en los principales mecanismos para ofrecer soluciones en materia de vivienda", porque eliminaron inversiones mayores en producción y responsabilidad pública de la deuda social.

Pero también estos gobiernos necesitaron poner la casa en orden. Para esto remodelaron las instituciones con el objetivo de hacerlas creíbles y eficaces y eficientes. Pero no contaron en el ámbito doméstico con aliados que aceptaran absorber los costos de una reforma (partidos políticos, gremios y sindicatos, burocracia tradicional) que debía racionalizar el gasto público en estructura, fondos y recursos humanos. Frente a esto las respuestas multilaterales provistas de técnicos con experticia modelaron nueva institucionalidad y nuevos recursos operacionales, imponiendo los modelos observables en the assistance provided to families to obtain credit, the financial sector and the private market turned into the main mechanisms to offer housing solutions" because they eliminated large investments in production and public responsibility from social debt.

Likewise, these governments had to put the house in order. To do so, they restructured their institutions in order to make them more credible, effective and efficient. However, they did not have local allies (political parties, guilds, unions and the traditional bureaucracy) willing to absorb the costs of a reform intended to cut public spending on structure, funds and human resources. Against this backdrop, multilateral answers provided by experts gave shape to a new institutionalism and operational resources, thus imposing the models observed in all Latin American countries. Generally speaking, the results of this initiative showed: a. an institutionalism that paved the way for the consolidation of the public administration model and decentralized entities with operational autonomy beyond their respective ministries;

28 Políticas que reflejan variaciones en el comportamiento del gasto público en cuanto al nivel, origen presupuestal y dinámica temporal del gasto (Pierson, 2006).

29 En contrario al modelo de bienestar que actuaba a la oferta llamando con sus planes a beneficiarios de varios grupos sociales, la identificación a la demanda supone que la ciudadanía es la que se organiza, demanda y en consecuencia se producen las políticas y planes. 
todos los países de América Latina. Los resultados a grandes rasgos muestran: a) una institucionalidad que abrió el paso al modelo de la gerencia pública con entes descentralizados con autonomía operativa más allá de los ministerios correspondientes; b) introducción del mercado productivo y financiero en la provisión de bienes sociales; y c) la continuidad en la reducción del rol del Estado en la planificación de la asequibilidad $^{31}$ de la vivienda mediante la apertura a intermediaciones entre mercado y familias, subsidios, préstamos, microcréditos y renuncias fiscales. Es este planteo el Estado se colocó definitivamente como facilitador de las condiciones de acceso, intermediando con un rol regulador entre sociedad y mercado. La diferencia con la etapa neoliberal que creó un mercado de vivienda es que ahora aparece la preocupación estatal en proveer asequibilidad y accesibilidad. Lo que no cambia es la orientación a dar en propiedad, el rol sustantivo del mercado y podemos hablar de la construcción de cuasi mercados de vivienda porque el Estado ha perdido el monopolio de la financiación, la producción y la distribución y es la competencia de mercado "[...] en función de maximizar las ganancias a través de la competencia o cuasi competencia de mercado lo que incentiva y obliga a las agencias contratadas a maximizar su eficiencia"32.

31 Asequibilidad es definida como "que se puede conseguir o adquirir"; referido a precio y condiciones "moderadas". Es diferente el concepto de accesibilidad que define "que permite un fácil acceso o entrada".

32 Narbondo, 2012, p. 8. $b$. the inclusion of the productive and financial markets in the provision of social goods; and $c$. the steady reduction of the role of the State in the planning of housing affordability ${ }^{31}$ measures through intermediation between the market and families, subsidies, loans, microcredits and tax waivers. The State, then, adopted a facilitator role by intermediating between the market and society. The difference between this stage and the neoliberal stage that created a housing market is the desire shown by the State to provide affordability and accessibility. What remains unchanged is the orientation to hand over the substantive role of the market; then, given the loss of the funding, production and provision monopoly on the part of the State, it is possible to talk about the construction of quasi-housing markets"[...] in terms of maximizing earnings through market or quasi-market competition, providing incentives and forcing hired companies to maximize their efficiency". ${ }^{2}$

How is housing policy systematically inserted? The third question says that governments articulate the housing issue as an economic and financial commodity and (through the power

31 Affordability is defined as what can be "achieved or acquired" in relation to "moderate" prices and conditions. Such a concept is different to that of accessibility, the latter defined as "easy access or entry".

32 Narbondo, 2012, p.8. 
¿Cuál es ahora la inserción sistémica de la política de vivienda? La tercera pregunta nos dice que habiéndose desarmado o debilitado la función social de las instituciones tradicionales, siendo sustituidas por agencias facilitadoras de transacciones entre mercado e individuos; los gobiernos articulan el tema vivienda como un producto económico y financiero a la vez que argumentan -por fuerza de su naturaleza política- su razón social. En su último informe para las Naciones Unidas, Rolnik analiza que: "La financiación de la vivienda también se ha convertido en un pilar central de los mercados financieros mundiales, y es fundamental para el desarrollo del sector financiero a nivel nacional e internacional." La autora declara en su informe que: "La mayoría de las políticas y estrategias de financiación [...] tienen por objetivo promover la propiedad y se basan en la premisa de que el mercado inmobiliario si se estructura y regula adecuadamente y está respaldado por el necesario marco jurídico e institucional, puede asegurar el acceso de todas las personas a una vivienda en propiedad adecuada y asequible"33.

Esta postura debilita la razón sectorial con que se relacionaba el área pública de la vivienda frente al Estado y el imaginario colectivo en el Estado de bienestar y reafirma la tendencia residual que como política social manifestaba en la etapa neoliberal del fin de siglo. El área de la vivienda se definió como una función social del Estado, cuando

33 Rolnik, 2012, p. 23. of its political power) argue about its social reason., once the social function is disabled or weakened within traditional institutions and then substituted by agencies facilitating transactions between the market and individuals. In her last report to the United Nations, Rodnik points out that: "The financing of housing has become a cornerstone of world financial markets and it is essential for the development of the financial sector at national and international level." This author also states that: "A large number of financing policies and strategies [...] aim at promoting property and are based on the premise that the housing market, if properly structured and regulated and supported by a legal and institutional framework, may ensure access to affordable and good-quality housing to as many people as possible."33

This stance weakens the sectoral reason that linked both public housing to the State and the collective imagination to the Welfare State, thus reaffirming the residual tendency that emerged during the neoliberal stage at the end of the XX century. The housing area was defined as a social function of the State when the latter intervened through programs aimed at addressing the social issue. This quality enabled the State to provide universal policies by way of the development of

33 Rolnik, 2012, p. 13. 
este intervenía a través de programas que daban dirección y entorno al problema social. Mediante esta cualidad el Estado proveía de políticas universales efectuando políticas sociales de vivienda para grupos medios y políticas de vivienda social de contenido focalizado con base a arreglos corporativos. Estos planes de gran profusión y escaso control estaban organizados y producidos por el propio Estado, mediados por la participación de varios niveles del Estado (central, regional, local) y por grupos organizados de la sociedad (cooperativas de ayuda mutua, de ahorro, gremios y sindicatos y empresarios que invertían en vivienda como función conexa a la fabril creando los barrios obreros). La participación ciudadana y civil fue también "el cemento" de la cultura política que guió al bienestar. Hoy la modalidad de facilitador es la mediación regulatoria y de control que adaptada a las características de cada país deja en libertad de acción a usuarios y proveedores. Esto significa entre otras cosas, la variación del concepto de la función de elaboración de políticas de vivienda. De las dos categorías anteriormente citadas, en Uruguay se ha pasado a la categoría de "vivienda de interés social", conceptualización que deja por el camino la naturaleza original del área, el involucramiento del Estado en la producción y distribución de los bienes y el área de derecho social de la ciudadanía. social policies on housing to middle groups and targeted social housing policies based on corporate arrangements. These widely spread and poorly controlled plans were organized and developed by the State and mediated by the participation of different State levels (central, regional and local) and organized groups (saving and credit cooperatives, guilds, unions and businessmen investing in housing as a function connected to industry, thus creating the working class neighborhoods). Citizen and civil participation was also the "mortar" of political culture during the welfare period. Today, the role of facilitator is the regulatory and control mediation which, adapted to the characteristics of each country, provides users and suppliers with freedom to operate. This entails, among other things, the variation of the concept related to the development of housing policies. As for the two above-mentioned categories, the "low-cost housing" is the one that is currently operating in Uruguay; such a conceptualization leaves behind the original nature of the area, the involvement of the State in the development and provision of goods and the social rights of citizens. 


\section{El caso uruguayo: la transformación sistémica del área desde 2005}

En este capítulo incursiono en el rumbo que tomó el área de vivienda en dos gobiernos consecutivos de izquierda en Uruguay (2005-2010 y 2010 al presente), analizando sobre sus hojas de ruta los resultados en tanto cambios y continuidades a procesos anteriores en materia de conceptualización y dirección del área pública de la vivienda. y los modelos de gobernanza que desarrolla a partir del trazado de sus objetivos y políticas. En primer término describo la herencia que recibieron los gobiernos del Frente Amplio en 2005, para continuar analizando las reformas que cambiaron sustantivamente la noción de vivienda social con que se fundaron las instituciones a principios del siglo $X X$. En esta parte abordo el relacionamiento de actores estatales y no estatales por considerar que en este factor se encuentran explicaciones del cambio.

\section{5-2010: PONER LA CASA EN ORDEN Y REORIENTAR LOS ROLES}

El gobierno frenteamplista de Tabaré Vázquez encontró en el área estatal de la vivienda un espacio vaciado de cometidos y contenidos. La primera decisión fue ordenar y racionalizar la función institucional. El default del BHU sin autonomía

ARTíCULO: El rol de las políticas de vivienda en la eficiencia sistémica de los países en desarrollo: análisis aplicado a la experiencia en Uruguay / Altair Jesica Magri Díaz

\section{The Uruguayan Case: The Systemic Transformation of the Area Sine 2005}

This chapter addresses the course taken by the housing area over two consecutive left-wing governments (2005-2010 and 2010 to the present) and analyzes its changes and continuities in relation to previous processes with respect to the conceptualization and direction of the public area of housing and the governance models developed according to goals and policies. First, this contribution describes the legacy of the governments belonging to the Frente Amplio in 2005 and then analyzes the reforms that substantively changed the notion of social housing upon which the foundation of institutions was based at the beginning of the XX century. This section deals with the relationship between State and non-State actors particularly due to the fact that some of the reasons that explain this change can be found here.

\section{5-2010: PUTTING THE HOUSE IN ORDER AND REORIENTATION OF ROLES}

The State area of housing had no goals or content when Tabaré Vásquez took up the presidency. His first measure was to organize and rationalize the 
financiera y bajo control del Ministerio de Economía y Finanzas (MEF) desde 2002, los altos niveles de corrupción política (con el procesamiento penal de jerarcas) y un modelo de gestión anacrónico y burocratizado no era funcional a los requerimientos del sistema financiero nacional e internacional.

La primera cuestión que se verifica en la propuesta programática del nuevo gobierno es el postulado que el Estado debe transformarse a sí mismo al tiempo que modificar las relaciones con una sociedad que manifiesta cada vez más complejidad en su propia estructura y sistema de vínculos en su interior, con el Estado y el sistema político. La propuesta del "Uruguay Social" reivindicó la vocación universalista e integral de las políticas públicas sin desconocer que el componente de emergencia social que se abatía sobre el país requería de una intervención urgente y focalizada. Pero entre el Programa que pretendía la inmediata solución a la demanda consolidada por vivienda (se calculaba en 80.000 familias) y la práctica se recorrió un largo trecho. En este sentido se entra en un proceso de recomposición institucional que empezó a cambiar a mitad de período la orientación social del área. Una primera medida del saneamiento institucional fue insertar el factor vivienda en el orden sistémico del Estado: por un lado que adquiriera responsabilidad financiera sobre sus activos y pasivos y por otro alinearlo a la senda de crecimiento y desarrollo económico del país. La inversión extranjera se hizo fuerte en el mercado inmobiliario, los agentes institutional function. The default of the BHU, which lacked financial autonomy and was under the control of the Ministry of Economy and Finance (MEF) since 2002, the high levels of political corruption (including the prosecution against high-ranked politicians) and an anachronistic and bureaucratized administration model were not compliant with the requirements of national and international financial systems.

The first aspect verified in the programmatic proposal of the new government is the postulate that the State has to transform itself and modify the relationship with a society that is ever more complex as far as its structure and relationships at internal, State and political levels are concerned. The "Uruguay Social" proposal claimed the universalist and integral vocation of public policies while acknowledging that the social emergency that was hitting the country needed an urgent and targeted intervention. However, there was a long gap between the Program intended to give an immediate solution to the housing demand (about 80,000 families) and its practical application. This was the beginning of the institutional restructure process which, midway through the presidential term, changed the social orientation of the area. Some of the first measures of this institutional reorganization was the inclusion of the housing factor in the systemic 
domésticos comenzaron a actuar en consecuencia volcados a segmentos de alta gama y las soluciones con contenido social no importaron al mercado. La carencia de interés del mercado ${ }^{34}$ fue por cierto escepticismo en que una orientación de izquierda diera cabida al interés privado y las efectivas capacidades de ordenar un área pública que se observaba en proceso de extinción.

\section{INSERTAR EL ÁREA DE VIVIENDA EN EL ORDEN SISTÉMICO DEL ESTADO}

Para acometer el cambio se necesitaban herramientas potentes que a la vez no generaran problemas de alcance político mayor en una fuerza política sin antecedentes gubernativos de nivel nacional. Un primer dilema seguía planteado en como quitar poder al Banco Hipotecario del Uruguay (estatizado en 1912) y a su burocracia a la vez que empoderar a un ministerio "mal burocratizado", con baja capacidad técnica y altamente politizado en la relación con la demanda. Para generar y regenerar el liderazgo público en materia de vivienda no había instituciones responsables y solventes a las cuales acudir. Eliminarlas significaba un costo político demasiado grande y había que pensar en un sustituto con la fuerza política suficiente para

34 El mercado fue marginal en el período del bienestar, se asoció al Estado para la vivienda focalizada para pobres en 1991 y en la provisión privada para grupos de clase media.

ARTíCULO: El rol de las políticas de vivienda en la eficiencia sistémica de los países en desarrollo: análisis aplicado a la experiencia en Uruguay / Altair Jesica Magri Díaz order of the State: on the one hand, there was a need for a financial responsibility over its assets and liabilities; on the other hand, such an area had to be aligned to the path of economic growth and development of the country. Likewise, there was a strong presence of foreign capital in the housing market and local agents began to operate focused on premium segments; the result was the neglect of social solutions. Such lack of interest ${ }^{34}$ was based on the doubts that a left-wing orientation would make some room for the private interest and the effective capacities to restructure a public area that was assumed to be on the verge of extinction.

\section{THE INCLUSION OF THE AREA IN THE SYSTEMIC ORDER OF THE STATE}

Such a change would need strong tools so as not to generate major political problems within an political force with no experience at governmental level. There was a dilemma regarding how to take power away from the Mortgage Bank of Uruguay (nationalized in 1912) and its bureaucracy while empowering an "incorrectly bureaucratized" ministry with low technical capacity and highly politicized in relation to demand. In addition, the

34 The decline in economic activity during the welfare period, it was associated with the State of focalized housing aimed at low-income groups in 1991 and the private provision of housing for middle-income groups.

revista invi № 79 / November 2013 / Volume № 28: 17-59 
desmontar el andamiaje histórico sin soliviantar los apoyos sociales y corporativos.

Otro dilema era que hacer con los deudores hipotecarios (deudores sociales) del Estado, donde las cooperativas de ayuda mutua y de crédito eran las principales implicadas. Estas organizaciones con capacidad de organización y presión fueron históricamente aliadas de la izquierda y enfrentarlas constituía un problema político entre el gobierno y el partido ${ }^{35}$. Ni el ministerio ni el banco tenían la fuerza suficiente para forzar a los deudores con una normativa inadecuada y estrecha en este sentido, por lo que poco podían hacer para sanear sus pasivos por deudas sociales. La reforma necesitaba de una nueva orientación que no encontrara obstáculos de actores corporativos y de la sociedad en su conjunto con capacidad de presionar e inmovilizar a la clase política.

En 2007 aparece la primera medida legal: la ley $\mathrm{N}^{\mathrm{o}}$ 18.125 reformó la gestión de tres campos sensibles a los intereses de un gobierno que contó con mayorías especiales a los efectos. Se reestructuraron las funciones del BHU remitiéndolo al área exclusivamente financiera, se creó la Agencia Nacional de Vivienda (ANV) como ente descentralizado y se elaboró un sistema de ejecución simplificada del crédito hipotecario para la vivienda, donde se obvió el sistema de intervención judicial existente

35 Un análisis en Magri, 2007. generation and regeneration of political leadership in terms of housing required responsible and solvent institutions. The elimination of these bodies would entail a high political cost, hence the need to find a substitute with the political strength to disassemble the historical structure without affecting social and corporate support.

Mortgage debtors (social debtors), and most especially support and credit cooperatives, represented another dilemma. These entities with organization and pressure capacity had been historically linked to the left-wing sector and facing them constituted a major political problem for the State and the governing party. ${ }^{35}$ Neither the ministry nor the bank had the power to force debtors with inappropriate and tight regulations due to the few options they had to pay their social debts. This reform needed a new orientation aimed at avoiding the obstacles put forward by corporate actors and a society with the capacity to exert pressure and immobilize the political class.

The first legal measure appeared on 2007. The Act $N^{\circ} 18,125$ reshaped the management area of three fields sensitive to the interests of a government with particular majorities. In this sense, the functions of the BHU were restructured to focus exclusively on the financial area, the National Housing Agency

35 See Magri, 2007. 
hasta la fecha ${ }^{36}$. Estas tres medidas tienen una fuerte conexión entre sí y apuntan a fortalecer la eficiencia y eficacia estatal en materia de manejo interno de fondos y relación con el público objetivo, dos factores que se fueron distorsionando en el correr de las décadas. En este paquete de medidas, se ubicaron definitivamente los roles y las funciones estatales y el nuevo tipo de relacionamiento del área estatal con la ciudadanía y el sector privado. La reforma puede distinguir ahora tres grandes actores: por un lado el BHU reducido a agente financiero en competencia con el sector privado y con el estatal Banco de la República (BROU); por otro el MVOTMA dedicado a ejecutar programas focalizados; y por otro la ANV que concentra la decisión y gestión operativa de los recursos institucionales y la gestión de deudores asumiendo un rol principal en materia de planificación y ejecución de planes de acceso a la vivienda que son implementados en su seno o en las otras dos instituciones de acuerdo a cada modalidad asignada. La ANV fue diseñada por un programa financiado por el $\operatorname{PNUD}^{37}$ y fue propuesta desde el ejecutivo nacional y aprobada por amplias mayorías (partido de gobierno y oposición). En el Capítulo no 2, Artículo 9º se

36 Un juicio ejecutorio de vivienda podía llevar más de una década. 37 Programa "Fortalecimiento institucional del MVOTMA y apoyo al diseño e implementación de la política habitacional". URU/05/005. Cofinanciación de U\$S 21.600 sobre total de U\$S 1.915.338. (PNUD, 2005)
(ANV) was created as a decentralized body and a housing debt recovery system was developed, disregarding the judicial intervention system ${ }^{36}$. These three measures have a strong connection and are intended to strengthen the efficiency and efficacy of the State in the administration of funds and the relationship with the target group, two factors that departed from their original purpose over the decades. The functions and role of the State and its new relationship with citizens and the private sector were included in this package of measures. This reform identifies three prominent actors: the BHU, the financial housing agent that competes with the private sector and the Staterun Bank of the Republic (BROU); the MVOTMA, which is in charge of the operation of targeted programs; and the ANV, which concentrates the decision and operative administration of institutional resources and the management of debtors by playing a key role in terms of the design and execution of housing accessibility plans implemented either internally or within the other two institutions according to each modality. The ANV was designed by a program funded by the PNUD ${ }^{37}$ and proposed by the Executive; it

36 A legal action involving housing might take more than a decade. 37 "Institutional Strengthening of MVOTMA and Support to the Design and Implementation of Housing Policies". URU/05/005. U\$S 21,600 co-financing against a total of US\$1,915,338. (PNUD, 2005). 
determina su creación: "Créase la Agencia Nacional de Vivienda como servicio descentralizado, con los fines, cometidos y atribuciones que especifica esta ley. En su actuación podrá identificarse también con la sigla 'ANV'; en la presente ley se la menciona como "la Agencia'. La creación del nuevo organismo fue argumentada como un sistema que [...] tiene como finalidad promover y facilitar el acceso a la vivienda de conformidad al art. 45 de la Constitución de la República $^{38}$, así como contribuir a la elaboración e implementación de las políticas públicas en materia de hábitat urbano"39.

Sus funciones fueron:

a. "a. Ejecutar programas de vivienda y desarrollo urbano en acuerdo con entidades públicas $y$ privadas.

b. Desarrollar y gestionar instrumentos financieros que faciliten el acceso al financiamiento de la vivienda.

c. Actuar en el mercado inmobiliario como inversionista y gestor de emprendimientos en áreas urbanas.

d. Además, administrará activos de cartera de créditos para la vivienda".

38 En 1945 la reforma constitucional inserta al mercado como socio y proveedor, aunque este papel no fue desempeñado hasta la reforma liberal de 1991 y aún así fue relativo por el poder del BHU.

39 Sesión Ordinaria CC.RR del Uruguay, 18/7/2007, p. 44. was approved by a large majority (government and opposition parties). The creation of these bodies is enshrined in Chapter $n^{\circ} 2$, Article $9^{\circ}$ : The National Housing Policy is hereby established as a decentralized service, with the purpose, duties and power as specified by law. This entity may be identified as ANV" though this Act refers to it as the "Agency". The creation of this new entity was argued as a system that "[...] is intended to promote and facilitate the access to housing according to the Art. 45 of the Constitution of the Republic ${ }^{38}$ and contribute to the development and implementation of public policies in terms of urban habitat ${ }^{39}$.

\section{Its responsibilities included:}

a. "Implementing housing and urban development programs in accordance with public and private entities

b. Developing and managing financial instruments aimed to facilitate the access to housing finance

c. Acting in the housing market as an investor and manager of projects in urban areas

38 In 1945, the constitutional reform regarded the market as a partner and supplier; however, this function was not performed until the liberal reform of 1991. The power of the BHU downplayed its importance.

39 Ordinary session, House of Representatives, Uruguay, 07/18/2007, p. 44. 
En la declaración de las metas y objetivos de la ANV se expone "Ser una entidad que cuente con las capacidades necesarias que le permita prestar servicios de excelencia para la ejecución de politicas y programas de hábitat urbano definidas por las autoridades nacionales y departamentales, integrando las dimensiones económicas, sociales y medioambientales".

La ANV se convirtió en el eje ejecutivo del área, teniendo directa información y control sobre las actividades del ministerio y del BHU por ser el organismo creador de las líneas de políticas ejecutadas por estos. Se programaron una serie de instrumentos como crear y gestionar sistemas de seguros de créditos hipotecarios, fondos de garantía, desarrollo de instrumentos de reducción de costos de fondeo de la actividad hipotecaria a determinados sectores de la población y capacidad de actuar en el mercado inmobiliario como inversionista en calidad de único propietario o en asociación con privados.

En esta fase, las expectativas fueron superlativas respecto al lugar de privilegio que ocuparían los "socios sociales" de la izquierda (cooperativas) y se mostraban más cautas desde los agentes de mercado. Pero la ANV no se apoyó en socios políticos, generando una línea de políticas independiente del ministerio y del banco, constriñendo la operativa de estos y la capacidad de presión de grupos corporativos de corte social (cooperativas). La ANV trabaja con bajo perfil mediático, sin exponerse al

\section{d. Administrating housing credits"}

The declaration of the goals and objectives of the ANV states that the latter should be "An entity with the necessary capacities to serve excellence in the implementation, through the inclusion of the economic, social and environmental dimensions, of urban habitat policies and programs defined by national and local authorities".

Being the creator of the policies implemented by the ministry and the BHU, the ANV was provided with direct information and controlled the activities of these entities, thus becoming the executive axis of this area. Likewise, a series of instruments were programmed; these include the creation and management of a credit insurance system for mortgages, guarantee funds, the development of instruments for the reduction of housing funding costs to certain segments of the population and the capacity to invest in the housing market as sole owner or in association with private entities.

There were great expectations regarding the prime position left-wing "social partners" (cooperatives) would hold during this stage; market agents were more cautious about it. However, the ANV did not rely on political partners, thus generating a line of policies running independently from the ministry and the bank. Such an action resulted 


\section{TABLA 1: SOLUCIONES A MOROSIDAD ANTIGUA, NUEVOS INSCRIPTOS Y VIVIENDAS EJECUTADAS Y EN PROCESO ENTRE 2011 Y 2012.}

\begin{tabular}{llll} 
Morosidad 52.063 familias & Deudas hipotecarias & Nuevas viviendas y proyectos & $\begin{array}{l}\text { Inscriptos a vivienda usada: } 7819 \\
\text { familias }\end{array}$ \\
\hline A remate: $51 \%$ & Cancelan 22\% & 6390 viviendas & Adjudicadas: 1183 \\
\hline $\begin{array}{l}\text { Arreglos: } 49 \% \\
\text { Ya cancelaron 22\% }\end{array}$ & Refinancian 88\% & 210 de obra cooperativas & $\begin{array}{l}\text { En proceso: } 252 \\
\text { Ya entregadas: } 931\end{array}$ \\
\hline
\end{tabular}

Fuente: elaboración propia con datos de ANV 2013.

TABLE 1: SOLUTIONS TO ARREARS, NEW REGISTRATIONS AND INTERVENED DWELLINGS BETWEEN 2011 AND 2012.

\begin{tabular}{llll} 
Arrears: 52,063 families & Mortgage Debts & New dwelligs and projects & $\begin{array}{l}\text { Registered in the pre-owned housing } \\
\text { program: } 7,819 \text { families }\end{array}$ \\
\hline Auctioned: $51 \%$ & Current $22 \%$ & 6,390 dwellings & Recipients: 1183 \\
\hline $\begin{array}{l}\text { Settlements: } 49 \% \\
\text { Paid22\% }\end{array}$ & Refinanced $88 \%$ & $\begin{array}{l}210 \text { from cooperative } \\
\text { initiatives }\end{array}$ & In process: 252 \\
Handed over: 931
\end{tabular}

Source: Author's elaboration based on ANV data

debate público, en consonancia con las ideas de dirección de nueva gerencia pública. Sin embargo es posible observar su eficiencia y efectividad en tanto redujo la cartera de morosos, ejecutó miles de viviendas impagas o con atrasos y delineó las políticas de las otras instituciones del rubro, fomentando la línea de compra de vivienda. En la Tabla 1 se muestran datos proporcionados por la ANV en relación al período entre marzo de 2011 y marzo de 2012:

48 revista invi № 79 / Noviembre 2013 / Volumen № 28: 17-59 in the operative restriction of the latter and the reduction of the pressure capacity on the part of corporate social groups (cooperatives). The ANV holds a low media profile, maintaining a distance from the public debate in line with the principles of the new public managerialism. It is possible, though, to observe its efficiency and effectiveness in the reduction in the number of defaulters, the resolution of mortgage defaults and delinquencies 
Toda la operativa institucional reformuló la inserción del área en el conjunto del Estado. En este primer quinquenio de la izquierda el ordenamiento institucional se organizó para ligar el aspecto económico y productivo a un sector tradicionalmente vinculado al área social. Posteriormente otra ley de importancia concreta el cambio.

\section{0-LA ALIANZA PARA EL CAMBIO: NGP Y PARTICIPACIÓN DEL MERCADO}

A instancias de la ANV se aprueba en 2011, también con votos del FA y oposición la ley de Promoción a la Inversión Privada de Vivienda de Interés Social (ley $\mathrm{n}^{\circ}$ 18.795), que establece la intervención del mercado en la financiación y venta de viviendas no suntuarias mediante la regulación y control del Estado. Los principales objetivos de la ley son: aumentar la cantidad de viviendas disponibles y mejorar las condiciones de financiamiento y garantía de crédito hipotecario. En este sentido, a instancias de la ANV se replanteó el concepto social tradicional a la vivienda en tres tipos de acceso: a) vivienda social para grupos carenciados implementada por ANV y ministerio con subsidios parciales o totales de familias registradas por sus ingresos; b) vivienda de mercado para grupos con capacidad de acceso (ingresos y ahorros); y c) se introduce el concepto de vivienda de interés social, una categoría intermedia dentro de la cual se genera una red de proveedores, usuarios y clientes

ARTíCULO: El rol de las políticas de vivienda en la eficiencia sistémica de los países en desarrollo: análisis aplicado a la experiencia en Uruguay / Altair Jesica Magri Díaz and the outline of policies for other institutions, stimulating the purchase of dwellings. Table 1 shows data provided by the ANV in relation to the March, 2011 and March, 2012 period. See Table 1 .

This institutional operation reformulated the inclusion of the housing area in the State planning. Over the first five years of leftist administration the institutional restructuring was meant to link the economic and productive aspects to a traditionally social area. Subsequently, other important act would concrete such a change.

\section{THE ALLIANCE FOR CHANGE: NGP AND PARTICIPATION IN THE MARKET}

In 2011, at the request of the ANV and supported by votes from the Frente Amplio and the opposition, the Promotion to the Private Investment in LowCost Housing Act $\left(\mathrm{N}^{\circ}\right.$ 18,795) was adopted. Through the regulation and control of the State, this act established the intervention of the market in the financing and selling of non-sumptuary housing. The main objectives of this act are: increasing the number of available dwellings and improving the financing and guarantee conditions of the mortgages. In this sense, the ANV rethought the traditional social concept of housing in three types of access: a. social housing for vulnerable 
en relación privada controlada por la normativa estatal pero con autonomía de transacciones y financiamiento entre privados. La introducción de este nuevo concepto apunta a la propiedad del bien consolidando en Uruguay las líneas que se desarrollan en otros países. El Estado regula las condiciones de acceso y provisión (financiación, calidad, precios) respondiendo a la necesidad de cubrir la demanda de los grupos intermedios con capacidad de pago y sin capacidad de ahorro previo o seguridad de poder transar con el mercado debido a su situación económica actual y futura, a los cuales el Estado no considera pasibles de políticas focalizadas ni beneficiarios de préstamos o subsidios. El Estado juega un papel de facilitador del acceso a las familias y el mercado es beneficiado con renuncias fiscales muy importantes. A la vez, la vivienda de interés social se transforma en un factor que incide en las condiciones macroeconómicas favorables a la inversión privada y al aumento de la competitividad sistémica del país porque moviliza la inversión, la cadena productiva industrial y el empleo. Los objetivos declarados en el cuerpo legal crean: a) fondos de garantía hipotecaria donde el Estado asume o respalda con subsidios del 20\% la entrega inicial del 30\% (el otro $10 \%$ va por parte del comprador que aporta el ahorro previo); y b) el financista privado corre con el 70\% restante y es eximido de aportes fiscales (como el IVA, el IRAE, trasmisión patrimonial, groups, implemented by the ANV and ministry with partial or total subsidy for families according to income; b. market housing for groups with access to financing (income and savings); and c. low-cost housing, an intermediate category that includes a network of suppliers, users and clients operating privately according to State regulations but with autonomy of transactions and funding between private parties. The introduction of this new concept is oriented towards the property over the housing asset, consolidating the lines of action developed in other countries. The State regulates the access and provision conditions (funding, quality and prices), thus meeting the needs of intermediate groups with the ability to pay and no saving capacity or certainty to incur into financial obligations due to their current and future economic condition; this group is not regarded by the State as a recipient of focalized policies, loans or subsides. The State plays the role of the facilitator of access to families and the market benefits from important tax waivers. At the same time, the low-cost housing becomes a factor that impacts the macroeconomic conditions that favor private investment and the increase of systemic competitiveness due to the mobilization of investment, the industrial production chain 
TABLA 2: PRECIOS ESTIMATIVOS DE M² DE SUELO Y M² CONSTRUCCIÓN SEGÚN ZONAS DE MONTEVIDEO Y CANELONES.

\begin{tabular}{lll}
\hline Zona Mdeo/Can. & Precio promedio suelo & Precio m² construcción \\
\hline Zona costera & US\$544 & US\$ 1581 \\
\hline Zona centro & US\$459 & US\$ 1290 \\
\hline Zona periferia & US\$34 & US\$ 979 \\
\hline
\end{tabular}

Fuente: elaboración propia con datos INE 2013 y Revista Propiedades 2013

Precios aproximados de acuerdo a la tipología, estructura y calidad

TABLE 2: APPROXIMATE PRICE OF M2 OF LAND AND M2 OF LAND FOR CONSTRUCTION IN MONTEVIDEO AND CANELONES

\begin{tabular}{lll} 
Mdeo/Can Area & Average Price of Land & Price of $\mathrm{m}^{2}$ for Construction \\
\hline Coastal Area & US\$544 & US\$ 1581 \\
\hline Central Area & US\$459 & US\$1290 \\
\hline Periurban Area & US\$34 & US\$979 \\
\hline
\end{tabular}

Source: Author's elaboration based on data retrieved from INE 2013 and Revista Propiedades 2013.

Estimated price according to typology, structure and quality.

\section{TABLA 3: EVOLUCIÓN DE LOS PRECIOS DE VIVIENDAS DE DOS Y TRES DORMITORIOS CALIDAD MEDIA}

\begin{tabular}{lll}
\hline Cantidad Dormitorios & Precio en US\$ 2011 & Precio en US\$ 2013 \\
\hline 2 dormitorios $\left(44\right.$ a $\left.69 \mathrm{~m}^{2}\right)$ & Máximo US\$ 96.567 & proxy $133.600^{*}$ \\
\hline 3 dormitorios $\left(68\right.$ a $\left.107 \mathrm{~m}^{2}\right)$ & Máximo US\$ 119.917 & proxy $167.800^{*}$ \\
\hline
\end{tabular}

Fuente: Elaboración propia con datos de ANV, Revista Propiedades y weigelhaller.com.uy.

Se toma un promedio de la oferta observada en web de ANV entre junio y agosto 2013.

\section{TABLE 3: PRICE EVOLUTION OF TWO AND THREE-BEDROOM HOUSING}

\begin{tabular}{lll}
\hline Number of Rooms & Price US\$ (2011) & Price US\$ (2013) \\
\hline 2 Rooms $\left(44\right.$ to $\left.69 \mathrm{~m}^{2}\right)$ & Maximum US\$96.567 & proxy $133.600^{*}$ \\
\hline 3 Rooms $\left(68\right.$ to $\left.107 \mathrm{~m}^{2}\right)$ & Minimum US\$ 119.917 & proxy $167.800^{*}$ \\
\hline
\end{tabular}

Source: Author's elaboration based data retrieved from ANV, Revista Propiedades and weigelhaller.com.uy

This is an average of the supply observed at the ANV website between June, 2013 and August, 2013. 
$\mathrm{IRPF}^{40}$, contribución inmobiliaria urbana, entre otros). Los resultados a la fecha de elaboración de este artículo son auspiciosos. El mercado de alta gama comenzó a saturarse ${ }^{41}$ y comenzó a dar las respuestas esperadas referidas al "interés social", aunque la demanda instalada de familias interesadas, los ajustes salariales y de materiales elevaron el costo del $\mathrm{m}^{2}$ de construcción. También sube su valor al ritmo de la demanda el valor del suelo, en especial en la ciudad de Montevideo y su zona metropolitana y en el departamento y ciudad de Maldonado. La relación de precios de suelos, metro cuadrado de construcción, y precio final a la venta se elevó entre el inicio del programa a la fecha. La tabla 2 muestra el precio de los factores y el cuadro tercero la evolución entre 2011 y 2013 de los precios de vivienda media en un sector que comenzó a manifestar gran dinamismo en oferta a grupos de ingresos medios y medios altos.

\section{A manera de reflexiones finales}

El Estado uruguayo ha entrado definitiva y ordenadamente en la estrategia de financiación a la

40 IVA: impuesto al valor agregado; IRAE: impuesto a las actividades económicas; IRP: impuesto retribuciones personales.

41 Inversión inmobiliaria en Punta del Este, Maldonado, por ejemplo las torres del norteamericano Donald Trump, de inversores chilenos, argentinos, alemanes y brasileros. and employment. The objectives declared in the body of law include: a. mortgage guarantee funds where the State provides a subsidy of $20 \%$ the initial down payment of 30\% (the remaining 10\% is paid by the buyer who contributes his savings); $b$. the private creditor covers the remaining $70 \%$ and is exempt from taxation (VAT, ITEA, inheritance, PIT $^{40}$, urban real estate contribution, among others). The results achieved to the date of the elaboration of this paper are promising. The premium market become saturated ${ }^{41}$ and provided the expected answers related to the "social interest", even though the demand of interested families, the adjustments of salaries and the cost of materials raised the price of the square meter for construction. Land is also increasing in price, especially in Montevideo (and its metropolitan area) and in the department and city of Maldonado. There was an increase in the price relationship among land, squared meters for construction and the final sale price since the inception of the program and the elaboration of this research. Table 2 shows the price of factors and Table 3 represents the evolution of housing prices between 2011 and 2013 in an area with great

40 VAT: Value-added Tax; TIEA: Income Tax on Economic Activities; PIT: Personal Income Tax.

41 Investment property in Punta del Este, Maldonado such as the towers belonging to Donald Trump and operated by Chilean, Argentinean, German and Brazilian investors. 
vivienda social y de interés social. La orientación dominante en los dos últimos gobiernos considera que el mercado "refrenado" es un proveedor confiable para sustituir líneas que el área pública y la política no están dispuestos a asumir.

La concepción actual que trasciende orientaciones políticas relacionadas al valor agregado de la función estatal en la cuestión social llevadas adelante por el Estado de bienestar del siglo XX y apoyadas tradicionalmente por la izquierda nacional, ha quedado relegada por la orientación del gobierno a considerar cursos de acción donde el factor vivienda es un componente de competitividad del país, incidiendo en la economía, la producción, el empleo y en consecuencia en el bienestar público.

Como Uruguay entra en las tendencias mundiales con ciertos retrasos, toma de otras experiencias los costos políticos y sociales que acarrean las reformas. En el caso de la aplicación de la ley de inversión privada a la vivienda de "interés social", el Estado no toma costos económicos pues en primer término asume sólo el 10\% de una posible deuda, y segundo traslada al mercado financiero y productivo los instrumentos de ejecución inmediata.

Esto, si bien no es un costo económico puede significar a mediano o largo plazo costos políticos si el Estado no controla al mercado en las condiciones que les concede en tanto renuncia fiscal, calidad de vida y mecanismos de ejecución sumaria de deudores.

ARTíCULO: El rol de las políticas de vivienda en la eficiencia sistémica de los países en desarrollo: análisis aplicado a la experiencia en Uruguay / Altair Jesica Magri Díaz dynamism in housing supply oriented to middle and high-income groups. See Tables 2 and 3.

\section{Conclusions}

The Uruguayan State has definitely and orderly entered into the strategy aimed at financing social housing and low-cost housing. The dominant orientation over the last two presidential periods suggests that a "restrained" State is a reliable supplier that may address the lines of action that politics and the public area are not willing to deal with.

The current conception that transcends political orientations related to the added value of the State function in the social issue (carried out by the welfare State of the XX century and traditionally supported by the national left-wing sector) has been relegated by the idea of the government to think of housing as a competitiveness factor that affects the economy, production, and employment areas and the public welfare as a whole.

Given its late entry into this global trend, Uruguay was able to benefit from the experiences of other countries and learned the political and social costs associated with the implementation of reforms. In the case of the Promotion to the Private Investment in Low-Cost Housing act, 
Coincidiendo con el informe de Rolnik, observamos que dadas las condiciones de precios y ahorro previo exigidos no se garantiza la inclusión de grupos que puedan quedar en el medio entre el subsidio estatal para vivienda social y el fondo de garantía hipotecaria que realiza el Estado en el plan de interés social. Tampoco garantiza que la acción estatal atienda a los grupos más pobres, sin garantías por falta de inserción en el sistema. De hecho la experiencia del Plan Juntos impulsado por iniciativa personal del presidente Mujica está por fuera de la institucionalidad formal y no logra llegar con eficacia al 1.6\% de la población considerada en condición de indigencia.

En términos más generales que el caso uruguayo, puede observarse en la región latinoamericana un traslape de la cuestión social tal como la que se desarrolló en la primera mitad del siglo $\mathrm{XX}^{42}$. Si bien se asume este problema, la naturaleza social que las áreas de vivienda desarrollaron en el bienestar basado en un universalismo declarado y apoyado por las élites políticas donde las políticas públicas focalizadas eran accesorias y tenían un sentido claro de inclusión, ha sido transformada. Si bien se reconoce que la focalización en políticas tiene

42 Experiencias de caso expuestas por representantes de todos los países de América Latina en el Congreso de CLACSO “Hábitat popular e inclusión social", Río de Janeiro 10/2012, el cual integra la autora de este artículo. the State does not shoulder the economic cost of such an edict because it only assumes the 10\% of a possible debt and transfers the instruments for immediate implementation to the financial and productive markets.

Despite not involving an economic cost, such a measure may imply political costs in the mid and long terms if the State does not control the market in terms of tax exemption, quality of life and mechanisms to legally act against debtors.

Concurring with the report prepared by Rolnik, the prices and previous savings required to apply for housing benefits do not ensure the inclusion of groups with no access to either the State subsidy for social housing or the mortgage guarantee fund. Likewise, such conditions do not ensure the provision of State assistance to the poorest groups, with no guarantees in case of lack of integration within the system. In fact, the Plan Juntos, promoted by President Mujica, operates independently from formal institutions and has difficulties reaching the $1,6 \%$ of the population considered indigent. 
un carácter de inclusión, las mismas están siendo observadas con una mirada de cuasi mercado. Primero, porque el Estado se desprende de la intervención, dejando al sector privado el manejo de la transacción, el relacionamiento con los compradores, la calidad de las viviendas y su localización territorial que no tiene relación con el concepto de hábitat. En consecuencia, esta tendencia está soslayando el concepto de derecho ciudadano a la vivienda y al hábitat adecuado. Segundo, porque el concepto de accesibilidad y asequibilidad refiere solamente al factor financiero, dejando liberado al Estado de otras responsabilidades que atañen a la planificación, la implementación, el control y la evaluación de las acciones. Todas estas dimensiones son componentes de la matriz de una política pública que no son alcanzados por una gestión gerencial basada en indicadores de resultados de eficiencia. Por otro lado, la participación ciudadana como bien político de las democracias se diluye por la remercantilización en la prestación de bienes sociales, el Estado presente en alguna primera instancia facilitadora no tiene más incumbencia en el proceso. Se diluye en definitiva un elemento que hace a la construcción de las sociedades y del territorio nación porque se pierden de vista las necesidades (sólo se atienden "interesados", las

ARTíCULO: El rol de las políticas de vivienda en la eficiencia sistémica de los países en desarrollo: análisis aplicado a la experiencia en Uruguay / Altair Jesica Magri Díaz
In general terms, it is observed that the Latin American region is experiencing an overlap of the social issue, just as in the first half of the $X X$ century. ${ }^{42}$ While this problem is assumed, there has been a change in the social nature developed by the housing area, which was based on universalism and supported by political elites with inclusive policies. These policies, in turn, are being observed under a quasi-market perspective. Firstly, this is due to the detachment of intervention on the part of the State, leaving the task of handling transactions, the relationship with buyers, the quality of dwellings and the territorial localization that is not related to the concept of habitat in the hands of the private sector. Therefore, this tendency is avoiding the right of citizens to housing and a proper habitat. Secondly, the concepts of accessibility and affordability refer only to the financial factor, releasing the State from responsibilities such as the planning, implementation, control and evaluation of actions. These dimensions are part of a public policy that is not governed by a managerial administration based on efficiency indicators. Likewise, the role of civil participation, regarded as a political asset of democracies, is lessened as a consequence

42 Case experiences expounded by representatives from all Latin American countries at the "Popular Habitat and Social Inclusion" CLACSO Conference, Río de Janeiro 10/2012. The author of this research took part in this event.

revista invi № 79 / November 2013 / Volume № 28: 17-59 
demandas que se diluyen porque no hay referentes públicos a los cuales acudir). Se promueve la propiedad como bien transable con incidencia en el crecimiento económico familiar pero no se contempla el desarrollo que contiene más factores, ajenos a las finanzas. En suma, la política de vivienda como bien social se ha integrado a un proceso sistémico en el cual es receptora de intereses ajenos a la cuestión social. Ha perdido o está perdiendo su poderosa razón social, ahora pesa la competitividad sistémica del Estado en términos de crecimiento económico sin certezas de que en algún momento, vuelva a tener lo social un peso sustantivo. La teoría liberal del crecimiento por derrame ha insuflado las orientaciones públicas en políticas de vivienda: cuanto más estén insertos los individuos en el mismo, más oportunidades tendrán de acoplarse a la gobernanza de cuasi mercado en vivienda impulsada por el Estado, donde este es ahora uno más de los actores con capacidad de decisión.

\section{Bibliografía}

AGUILAR VILLANUEVA, Luis F. Gobernanza y gestión pública. México, Fondo de Cultura Económica. 2006.

AGENCIA Nacional de Vivienda. Ciudad de las 3 Cruces (segunda etapa de comercialización). Tu lugar en el corazón de la ciudad, vos a un paso de todo. of the re-commodification in the provision of social goods; in this scenario, the State, after its initial facilitating role, has no incidence in this process. Such a circumstance dilutes an element that associates the construction of cities and the territory with the concept of nation (all needs are disregarded and only those "interested" are taken into consideration, the rest of demands are diluted because there are no public entities available). Property is promoted as a tradable asset that affects the economic growth at family level; however, the rest of the factors other than finance are not included in this conception. In short, the housing policy, seen as a social good, has been included in a systemic process to operate as the recipient of interests alien to the social issue. This means that the housing dimension has lost or is losing its social purpose, what matters now is the systemic competitiveness of the State in terms of economic growth. In this connection, the question remains whether this social dimension will recover its substantial role within the public structure. The liberal theory of growth has subsumed the public orientation of housing policies: the more involved people are in this process, the more opportunities they have to suit the quasi-housing market promoted by the State, the latter being just another actor with decisionmaking capacity. 
[En línea]. ANV-Agencia Nacional de Vivienda. s.f. Disponible en: http://www.anv.gub.uy/home/contenido.aspx?id_contenido=215.

ARRIAGADA, Irma. Cambios de las políticas sociales: políticas de género y familia. [En línea]. Santiago de Chile, CEPAL. 2006. Serie Políticas Sociales No119. Disponible en: http://www.eclac.org/publicaciones/xml/3/24453/sps119_lcl2519.pdf.

BOSCHI, Renato y GAITÁN, Flavio. Gobiernos progresistas, agenda neodesarrollista y capacidades estatales: la experiencia reciente en Argentina, Brasil y Chile. En: LIMA, Maria Regina Soares de. Desempenho de governos progressistas no cone sul: agendas alternativas ao neoliberalismo. Rio de Janeiro, Edições IUPERJ. 2008. 285 p. ISBN 9788598272153

CASACUBERTA, Carlos. Situación de la vivienda en Uruguay: informe de divulgación. [En línea]. Montevideo, Instituto Nacional de Estadística. 2006. Disponible en: http://www.ine.gub.uy/ enha2006/ENHA_Vivienda_\%20Final_Corr.pdf.

CERRILLO I MARTÍNEZ, Agustín, comp. La gobernanza hoy: 10 textos de referencia. Madrid, Instituto Nacional de Administración Pública. 2005.

CROZIER, Michel, HUNTINGTON, Samuel P. y WATANUKI, Joji. The Crisis of Democracy. Report on the Governability of Democracies to the Trilateral Comisión. New York, New York University Press. 1975
DAHL, Robert Alan. La poliarquía. En: Un prefacio a la teoría democrática. Buenos Aires, Grupo Editor Latinoamericano. 1989.

ECHEBARRÍA, Koldo. Objetivar la gobernanza: funciones y metodología. Una aproximación a la objetivación del análisis institucional a través de indicadores de gobernabilidad. Congreso Internacional del CLAD sobre la Reforma del Estado y de la Administración Pública ( $9^{\circ}$, Madrid, España, 2004).

EASTON, David. Esquema para el análisis político. Buenos Aires, Amorrortu. 1973.

ESPING-ANDERSEN, Gøsta. Los tres mundos del estado de bienestar. Valencia, Alfons el Magnànim, Onstitució Valenciana d'estudis i investigació, Generalitat Valenciana. 1993

FLISFISCH, Angel. Gobernabilidad y consolidación democrática: sugerencias para la discusión. Revista Mexicana de Sociología. 51(3): 113-133, 1989.

FRANC0, Rolando. Estado, consolidación democrática y gobernabilidad en América Latina. Revista iberoamericana de autogestión y acción comunal. (2830): 129-152, 1993. ISSN 0212-7687.

GARRETÓN, Manuel Antonio. Neoliberalismo corregido y progresismo limitado: Los gobiernos de la Concertación en Chile, 1990-2010. Santiago de Chile, Arcis, CLACSO. 2012.

JESSOP, Robert. El futuro del estado capitalista. Madrid, De la Catarata. 2008.

revista invi № 79 / November 2013 / Volume N² 28: 17-59 
KATZMAN, Rubén. Notas sobre la medición de la vulnerabilidad social en las Encuestas de Hogares. Borrador de discusión de UCUDAL. Montevideo. 2000a.

- El aislamiento social de los pobres urbanos: reflexiones sobre su naturaleza, determinantes y consecuencias. Montevideo, paper UCUDAL. 2000b.

LAHERA, Eugenio. Introducción a las políticas públicas. México, Fondo de Cultura Económica. 2002.

MAGRI, Altair. Políticas de vivienda. En: MOREIRA, Constanza [et.al.] La hora de las reformas. Gobierno, políticas y actores en el Uruguay 20062007. Montevideo, Ediciones de la Banda Oriental. 2007. p. 209-214. Informe de coyuntura N7.

MAINTZ, Renate. El Estado y la sociedad civil en la gobernanza moderna. [En línea]. Revista del CLAD. (21), octubre 2001. Disponible en: http://www.clad.org/portal/publicacionesdel-clad/revista-clad-reforma-democracia/ articulos/021-octubre-2001/0041004

MARSHALL, Thomas Humphrey. Ciudadanía y clase social. Madrid, Alianza. 1998.

MENY, Ives y THOENIG, Jean Claude. Las políticas públicas. Barcelona, Ariel. 1992.

NARBONDO, Pedro. ¿Estado desarrollista de bienestar o construcción de la izquierda del Estado neoliberal? Los gobiernos del Frente Amplio de Uruguay. En: THWAITES REY, Mabel, ed. El Estado en América Latina: continuidades y rupturas. Santiago de Chile, Arcis, CLACSO. 2012. 303-337.
PIERRE, Jon. Debating governance: authority, steering, and democracy. Oxford, Oxford University Press. 2000.

PIERSON, Paul. Cuando el efecto es causa. Respuesta política y cambio político. Fotocopia FCS. s/f

- Sobrellevando la austeridad permanente. Reestructuración del Estado de bienestar en las democracias desarrolladas. Zona Abierta. (114/115): 43 120, 2006. ISSN 0210-2692.

PNUD Fortalecimiento institucional del MVOTMA y apoyo al diseño e implementación de la política habitacional. [En línea]. Programa de las Naciones Unidas para el Desarrollo. 2005. Disponible en: http://www.undp.org.uy/showProgram. asp?tfProgram $=163$

POLLITT, Christopher. Management techniques for the public sector: pulpit and practice. En: PETERS, Guy, ed. y SAVOIE, Donald, ed. Governance in a changing environment. Montreal, McGillQueen's Press. 1995. p. 203-238.

PRATS, Joan Oriol. El concepto y el análisis de la gobernabilidad. Revista Instituciones y Desarrollo. (14-15): 239-269, 2003

RHODES, R.W.A. Understanding governance: Policy Networks, Reflexibility and Accontability. London, Open University Press. 1997.

- Governance and Public Administration. En: PIERRE, Jon, ed. Debating Governance: Authority, Steering, and Democracy. Oxford, Oxford University Press. 2000. p. 54-90. 
ROLNIK, Raquel. Elderechoa una viviendaadecuada. [En línea]. Oficina del Alto Comisionado para los derechos humanos. 2012. Disponible en: http://www.ohchr. org/Documents/Issues/Housing/A-67-286_sp.pdf

ROSANVALLON, Pierre. La legitimidad democrática. Imparcialidad, reflexividad, proximidad. Buenos Aires, Manantial. 2009.
SOTO, Hernando de. El misterio del capital. Montevideo, El Observador. 2001.

VILAS, Carlos M. La izquierda latinoamericana y el surgimiento de regímenes nacional-populares. [En línea]. Nueva Sociedad. (197): 84-99, mayo 2005. ISSN 0251-3552. Disponible en: http:// www.nuso.org/upload/articulos/3261_1.pdf 